\title{
Pengaruh Pengawasan, Disiplin Kerja Terhadap Kinerja Pegawai di Dinas Pendidikan Kota Banda Aceh
}

\author{
Putri MAULIZA * \\ Fakultas Ekonomi, Universitas Serambi Mekkah, \\ Jalan Batoh, Lueng Bata, Kota Banda Aceh, Provinsi Aceh, Indonesia \\ putri_mauliza@yahoo.com
}

\section{Article's history:}

Received 15 February 2020; Received in revised form 17 July 2020; Accepted 21 August, 2020;

Published 30 August 2020. All rights reserved to the Lembaga Otonom Lembaga Informasi dan Riset Indonesia (KITA INFO dan RISET).

\section{Suggested citation:}

Mauliza, P. 2020. Pengaruh Pengawasan, Disiplin Kerja Terhadap Kinerja Pegawai di Dinas Pendidikan Kota Banda Aceh. JEMSI (Jurnal Ekonomi, Manajemen, dan Akuntansi), Volume 6 (2): 71-81. DOI: https://doi.org/10.35870/jemsi.v6i1.340.

\begin{abstract}
ABSTRAK:
Penelitian ini bertujuan untuk mengetahui pengaruh pengawasan, disiplin kerja terhadap kinerja pegawai di Dinas Pendidikan Kota Banda Aceh. Populasi penelitian ini berjumlah 83 orang pegawai, dan teknik pengambilan sampel dilakukan dengan metode sensus sehingga sampel dalam penelitian ini 83 orang pegawai. Model yang digunakan dalam penelitian ini adalah analisis regresi linier berganda. Hasil penelitian menunjukkan bahwa pengawasan dan disiplin kerja berpengaruh terhadap kinerja pegawai di Dinas Pendidikan Kota Banda Aceh, hal ini dibuktikan bahwa pengawasan dan disiplin kerja merupakan faktor yang mempengaruhi kinerja pegawai sebesar 60,6\% dan sisanya sebesar 39,4\% dijelaskan oleh variabel lain diluar dari pada penelitian ini, misalnya penghargaan, kompensasi, budaya organisasi, disiplin kerja dan lain-lain. Nilai koefesien korelasi (R) menunjukkan bahwa derajat hubungan (korelasi) antara pengawasan dan disiplin kerja dengan kinerja pegawai sebesar $77,8 \%$, artinya kinerja pegawai di Dinas Pendidikan Kota Banda Aceh mempunyai hubungan yang erat dan positif dengan pengawasan dan disiplin kerja. Hasil pengujian statistik menunjukkan bahwa pengawasan dan disiplin kerja secara simultan berpengaruh signifikan terhadap kinerja pegawai di Dinas Pendidikan Kota Banda Aceh, dengan nilai $F_{\text {hitung }}>F_{\text {tabel }}$ (81,932>3,112). Sedangkan secara parsial pengawasan dan disiplin kerja berpengaruh signifikan terhadap kinerja pegawai di Dinas Pendidikan Kota Banda Aceh, dengan nilai thitung $>$ tabel (3,300 dan 5,121>1,989). Berdasarkan hasil analisis regresi linier berganda dapat diketahui bahwa dari kedua variabel yang diteliti, ternyata variabel disiplin kerja $\left(X_{2}\right)$ mempunyai pengaruh paling dominan terhadap kinerja pegawai di Dinas Pendidikan Kota Banda Aceh, dengan nilai koefisien sebesar 0,487, kemudian diikuti oleh variabel pengawasan $\left(X_{1}\right)$ dengan nilai koefisien sebesar 0,281.
\end{abstract}

Kata Kunci: Pengawasan; Disiplin Kerja; Kinerja Pegawai.

JEL Classification: N01; Y80; J54.

\section{PENDAHULUAN}

Dalam rangka meningkatkan kinerja pegawai pemerintah khususnya jajaran pada Kantor Dinas Pendidikan Banda Aceh, diperlukan teknik kompetensi jabatan dan pengembangan karier yang efektif dimana ada pemahaman agar terciptanya sinergitas keberhasilan organisasi. Manajemen sumber daya manusia dapat diartikan sebagai pengelolaan dan pendayagunaan sumber daya yang ada pada pegawai. Pengelolan dan pendayagunaan tersebut harus di kembangkan secara maksimal dalam dunia bisnis untuk mencapai tujaun perusahaan dan pengembangan individu yang ada dalam perusahaan tersebut secara terpadu. Hal ini sejalan 
dengan pendapat bahwa manajemen sumber daya manusia bertujuan untuk pendayagunaan, pengembangan, penelitian, SDM dan SDA yang ada agar dapat di kelola secara efektif dan efesien yang bertujuan untuk mencapai tujuan organisasi (Samsudin, 2009:29).

Kinerja yang baik adalah kinerja yang optimal, yaitu kinerja yang sesuai standar organisasi dan mendukung tercapainya tujuan organisasi. Organisasi yang baik adalah organisasi yang berusaha meningkatkan kemampuan sumber daya manusianya, karena hal tersebut merupakan faktor kunci untuk meningkatkan kinerja pegawai. Menurut Setiyawan dan Waridin (2009:119) kinerja pegawai merupakan hasil atau prestasi kerja pegawai yang dinilai dari segi kualitas maupun kuantitas berdasarkan standar kerja yang ditentukan oleh pihak organisasi. Sebenarnya kinerja yang ditunjukkan oleh pegawai merupakan kelanjutan dari proses interaksi antara individu dan lingkungannya. Individu membawa tatanan organisasi, kemampuan, kepercayaan pribadi, pengharapan kebutuhan dan pengalaman.

Fenomena yang terjadi di Kantor Dinas Pendidikan Kota Banda Aceh bahwa kinerja pegawai pada instansi ini masih perlu pengembangan karena dengan adanya pengawasan dan disiplin kerja maka kinerja pegawai akan meningkat, sehingga pihak Kantor Dinas Pendidikan Kota Banda Aceh untuk meningkatkan kinerja pegawai maka diperlukan pengawasan dan disiplin kerja. Sumber daya terpenting bagi organisasi adalah orang-orang yang memberikan tenaga, bakat dan kreatifitas mereka pada organisasi. Karena itu kinerja organisasi baik itu organisasi bisnis maupun organisasi pemerintah tidak terlepas dari kinerja individu. Dalam hubungan ini faktor penempatan pegawai sebagai sumber daya manusia dalam bidang tugas tertentu dalam organisasi.

Kinerja pegawai dapat dicapai jika didukung oleh para pemimpin yang mengawasi kerjanya oleh sebab itu, dengan pengawasan dari masing-masing individu atau pengawasan dari pimpinannya itu merupakan hal yang sangat penting demi kelancaran pekerjaan yang dikerjakan. Pimpinan selain jadi motor penggerak juga berfungsi sebagai pengawas. Hal ini dimaksudkan agar pelaksanaan pekerjaanya dapat berjalan dengan lancar agar tujuan organisasi dapat tercapai. Pengawasan yang baik dapat berdampak baik juga terhadap pegawainya, karena mereka akan dapat menyelesaikan pekerjaannya dengan baik sehingga merekapun dapat berkonsentrasi terhadap tugasnya. Pegawai merupakan fokus utama dari pengawasan yang dilakukan oleh pimpinan harus dapat menunjukan prestasi yang baik dan mempunyai disiplin yang tinggi (Rahayu, 2008:2).

Pada dasarnya pengawasan berarti pengamatan dan pengukuran sesuatu kegiatan operasional dan hasil yang dicapai dibandingkan dengan sasaran dan standar yang telah ditetapkan sebelumnya. Pengawasan dilakukan dalam usaha menjamin kegiatan terlaksana sesuai dengan kebijakan, strategi, keputusan, rencana dan program kerja yang telah dianalisa, dirumuskan dan ditetapkan sebelumnya dalam wadah yang disusun (Siagian, 2009:98). Pengawasan kerja sangatlah penting dalam setiap pekerjaan baik itu, organisasi kecil maupun organisasi besar. Menurut Saydam (2009:198), melalui pengawasan dapat dipantau berbagai hal yang dapat merugikan organisasi, antara lain : kesalahan-kesalahan dalam pelaksanaan pekerjaan, kekurangan-kekurangan dalam pelaksanaan pekerjaan, kelemahan pelaksanaan dan cara kerjanya, rintangan-rintangan yang dialami maupun halhal lain yangmungkin akan dialami, kegagalan-kegagalan ataupun sukses-sukses yang dicapai dalam pelaksanaan pekerjaan.

Pengawasan sebagai salah satu kegiatan pengawasan merupakan tanggung jawab setiap pimpinan untuk menyelenggarakan manajemen atau administrasi yang efektif dan efisien dilingkungan instansi atau unit kerja masing-masing. Peningkatan fungsi pengawasan melekat dilingkungan Dinas Pendidikan Kota Banda Aceh bertolak dari motivasi untuk meningkatkan efisiensi dan efektivitas pelaksanaan tugas-tugas umum pemerintahan dengan cara peningkatan kinerja pegawai. Pelaksanaan pengawasan tersebut dapat mengurangi terjadinya berbagai kelemahan dan kekurangan aparatur pemerintah dalam melaksanakan tugas pokok masing-masing termasuk permasalahan tentang kinerja pegawai.

Dengan adanya pengawasan pimpinan/kepala instansi dapat mengetahui kegiatan-kegiatan nyata dari setiap aspek dan setiap permasalahan pelaksanaan tugas-tugas dalam lingkungan satuan organisasi yang masing-masing selanjutnya bilamana terjadi penyimpangan, maka dapat dengan segera langsung dinas pendidikan banda aceh mengambil langkah perbaikan dan tindakan seperlunya sesuai dengan rencana yang telah ditetapkan sebelumnya serta peraturan perundang-undangan yang berlaku. 
Disiplin yang baik tercermin dari besarnya rasa tanggung jawab seseorang terhadap tugas yang diberikan kepadanya. Maka peraturan sangat diperlukan untuk memberikan bimbingan dan penyuluhan bagi pegawai dalam menciptakan tata tertib yang baik di dalam organisasi, sebab kedisiplinan suatu organisasi dikatakan baik jika sebagian pegawai menaati peraturan-peraturan yang ada (Hasibuan, 2013:193-194). Keberhasilan organisasi sangat ditentukan oleh kualitas dan kinerja orang yang bekerja didalamnya. Kinerja adalah hasil kerja yang dicapai oleh seorang pegawai dalam melaksanakan tugas dan pekerjaan yang diwenangkan kepadanya selama periode tertentu. jika kinerja setiap pegawai yang ada di dalam suatu kantor baik, maka kinerja organisasi juga akan baik dan begitu pula apabila kinerja orang yang berada di dalam jelek, juga akan berdampak pada kinerja organisasi yang rendah pula, sehingga kinerja pegawai sangat menentukan kinerja organisasi tersebut.

Pada Kantor Dinas Pendidikan Kota Banda Aceh, permasalahan disiplin kerja pegawai sering kali. Hal ini tercermin dari sikap dan perilaku pegawai yang mangkir dari pekerjaan yang diberikan oleh atasannya, kebanyakan mengobrol saat jam kerja akibatnya pekerjaan yang bisa terselesaikan dalam waktu singkat memakan waktu yang panjang, datang dan pulang kantor tidak tepat waktu, tidak berada di tempat pada jam kantor sehingga pekerjaan menjadi terbengkalai.

Pimpinan mempunyai pengaruh yang sangat besar dalam menegakkan kedisiplinan, sebab pimpinan merupakan panutan dan sorotan dari bawahannya (Nitisemito, 2010:118). Pimpinan harus memberi contoh yang baik, berdisiplin baik, jujur, serta sesuai kata dengan perbuatan. Apabila teladan pimpinan baik, kedisiplinan bawahan pun akan ikut baik. Jadi pimpinan ikut berperan serta dalam menciptakan kedisiplinan pegawai, pimpinan harus mampu menggerakkan dan mengarahkan pegawai karena pimpinan bertanggung jawab terhadap keberhasilan dan kegagalan pegawai. Apabila instansi melaksanakan pengawasan secara baik sesuai dengan aturan yang telah ditetapkan dan dilaksanakan, maka dengan sendirinya disiplin kerja pegawai akan baik.

\section{TINJAUAN KEPUSTAKAAN}

\section{Kinerja Pegawai}

Menurut Moeheriono (2010:11) kinerja pegawai adalah hasil kinerja yang dapat dicapai oleh seseorang atau kelompok orang dalam suatu organisasi baik secara kualitatif maupun secara kuantitatif,sesuai dengan kewenagan,tugas dan tanggung jawab masing-masing dalam upaya mencapai tujuan organisasi bersangkutan secara legal,tidak melanggar hukum dan sesuai dengan moral ataupun etika.MenurutRivai dan Basri (2009:44) kinerja adalah kesediaan seseorang atau kelompok orang untuk melakukan sesuatu kegiatan dan menyempurnakannya sesuai dengan tanggung jawab dengan hasil seperti yang diharapkan. Menurut Mangkunegara (2013:67) menyatakan bahwa: "Kinerja adalah hasil kerja secara kualitas dan kuantitas yang dicapai oleh seorang pegawai dalam melaksanakan tugasnya sesuai dengan tanggung jawab yang diberikan kepadanya dalam waktu tertentu. Selanjutnya Mangkunegara menyebutkan bahwa kinerja merupakan suatu yang dapat dicapai, prestasi yang diperlihatkan dan kemampuan kerja".

Simamora (2009:327) menyatakan bahwa kinerja merupakan suatu pencapaian persyaratan-persyaratan pekerjaan tertentu yangakhirnya secara langsung dapat tercermin dari output yang dihasilkan baik jumlah maupun kualitasnya. Menurut Sedarmayanti (2011:260) kinerja merupakan sistem yang digunakan untuk menilai dan mengetahui apakah seorang karyawan telah melaksanakan pekerjaannya secara keseluruhan, atau merupakan perpaduan dari hasil kerja (apa yang harus dicapai seseorang) dan kompetensi (bagaimana seseorang mencapainya). Menurut Dharma (2009:35) penilaian kinerja didasarkan padapemahaman, pengetahuan, keahlian, kepiawaian dan prilaku yang diperlukan untuk melaksanakan suatu pekerjaan dengan baik dan analisis tentang atribut perilaku seseorang sesuai kriteria yang ditentukan untuk masing-masing pekerjaan.Kemudian Mahsun (2009:117) juga menyatakan bahwa kinerja adalah gambaran mengenai tingkat pencapaian pelaksanaan suatu kegiatan/program, kebijakan dalam mewujudkan sasaran, tujuan, visi dan misi organisasi yang tertuang dalam strategic planning suatu organisasi. 


\section{Pengawasan}

Dessler (2009:2) menyatakan bahwa pengawasan (Controlling) merupakan penyusunan standar seperti kuota penjualan, standar kualitas, atau level produksi; pemeriksaan untuk mengkaji prestasi kerja aktual dibandingkan dengan standar yang telah ditetapkan; mengadakan tindakan korektif yang diperlukan. Menurut G.R Terry dalam Hasibuan (2013:242) pengawasan adalah proses penentuan, apa yang harus dicapai yaitu standar, apa yang sedang dilakukan yaitu pelaksanaan, menilai pelaksanaan dan melakukan perbaikan-perbaikan, sehingga pelaksanaan sesuai dengan rencana yaitu selaras dengan standar. Menurut Mathis dan Jackson (2009:303) pengawasan merupakan sebagai proses pemantauan kinerja karyawan berdasarkan standar untuk mengukur kinerja, memastikan kualitas atas penilaian kinerja dan pengambilan informasi yang dapat dijadikan umpan balik pencapaian hasil yang dikomunikasikan ke para pegawai. Pengawasan adalah proses dimana pimpinan ingin mengetahui hasil pelaksanaan pekerjaan yang dilakukan bawahansesuai dengan rencana, perintah, tujuan, kebijakan yang telah ditentukan (Maringan, 2010:61). Menurut Siagian (2009:107) pengawasan adalah proses pengamatan daripada pelaksanaan seluruh kegiatan organisasi untuk menjamin agar supaya semua pekerjaan yang sedang dilakukan berjalan sesuai dengan rencana yang telah ditentukan sebelumnya. Menurut Harahap (2011:14) pengawasan adalah keseluruhan sistem, teknik, cara yang mungkin dapat digunakan oleh seorang atasan untuk menjamin agar segala aktivitas yang dilakukan oleh dan dalam organisasi benar-benar menerapkan prinsip efisiensi dan mengarah pada upaya mencapai keseluruhan tujuan organisasi.

Menurut Nawawi (2008:15) pengawasan adalah proses pemantauan, pemeriksaan dan evaluasi atasan langsung terhadap pekerjaan dan hasil kerja bawahannya agar dapat mencegah terjadinya penyalahgunaan wewenang dan penyimpangan dari ketentuan, ketentuan, peraturan-peraturan dan kebijakan yang telah ditetapkan. Dale dalam (Winardi, 2011:224) pengawasan tidak hanya melihat sesuatu dengan seksama dan melaporkan hasil kegiatan mengawasi, tetapi juga mengandung arti memperbaiki dan meluruskannya sehingga mencapai tujuan yang sesuai dengan apa yang direncanakan.

\section{Disiplin Kerja}

Menurut Rivai dan Sagala (2010:825)disiplin kerja merupakan suatu alat yang digunakan para manajer untuk melakukan komunikasi dengan tenaga kerja agar mereka bersedia untuk mengubah suatu perilaku serta sebagai upaya untuk meningkatkan kesadaran dan kesediaan seseorang mentaati semua peraturan.MenurutHasibuan (2013:193) kedisiplinan adalah kesadaran dan kesediaan sesorang mentaati peraturan perusahaan dan norma-norma sosial yang berlaku. Menurut Fathoni (2009:172) kedisiplinan adalah kesadaran dan kesediaan seseorang menaati semua peraturan perusahaan dan norma sosial yang berlaku.menurut Siswanto (2009:291) disiplin adalah suatu sikap menghormati, menghargai, patuh, dan taat terhadap peraturan-peraturan yang berlaku, baik yang tertulis maupun tidak tertulis serta sanggup menjalankannya dan tidak mengelak untuk menerima sanksi-sanksinya apabila melanggar tugas dan wewenang yang diberikan kepadanya.Keith Davis dalam Mngkunegara (2013:129) menyatakan bahwa: "Disiplin kerja adalah kegiatan manajemen untuk memperteguh pedoman-pedoman organisasional. Disiplin kerja yang baik mencerminkan besarnya rasa tanggung jawab seseorang terhadap tugas-tugas yang diberikannya. Hal ini mendorong gairah kerja, semangat kerja, dan terwujudnya tujuan perusahaan, tenaga kerjadan masyarakat". Terry dalam Sutrisno (2013:87) menyatakan bahwa: "Disiplin merupakan alat penggerak pegawai agar tiap pekerjaan dapat berjalan dengan lancar, maka harus diusahakan agar ada disiplin yang baik.perilaku tidak disiplin yang timbul merupakan cerminan dari persepsi negatif pegawai terhadap kontrol yang dilakukan oleh prilaku pimpinan. Sebaliknya perilaku disiplin seorang pegawai yang timbul merupakan cermilan dari persebsi positif terhadaap control atasan atau pimpinan".

Selanjutnya menurut Gozali Saydam (2009:284) disiplin kerja adalah sikap kesediaan dan kerelaan seseorang untuk mematuhi dan mentaati segala norma-norma peraturan yang berlaku disekitarnya.Menurut Nitisemito (2010:393) disiplin kerja adalah sikap, tingkah laku dan perbuatan yang sesuai dengan peraturan dari perusahaan baik yang tertulis maupun yang tidak tertulis.Menurut Handoko (2009:308) disiplin kerja adalah kegiatan manajemen untuk menjalankan standar-standar instansi 


\section{Kerangka Pemikiran}

Menurut Sugiyono (2014:60) kerangka pemikiran adalah model konseptual tentang bagaiman teori berhubungan dengan berbagai faktor yang telah diindetifikasikan sebagai hal yang penting. Dengan demikian maka kerangka berfikir adalah sebuah pemahaman yang melandasi pemahaman-pemahaman yang lainnya,sebuah pemahaman yang paling mendasar dan menjadi pondasi bagi setiap pemikiranatau suatu bentuk proses dari keseluruhan penelitian yang akandilakukan.

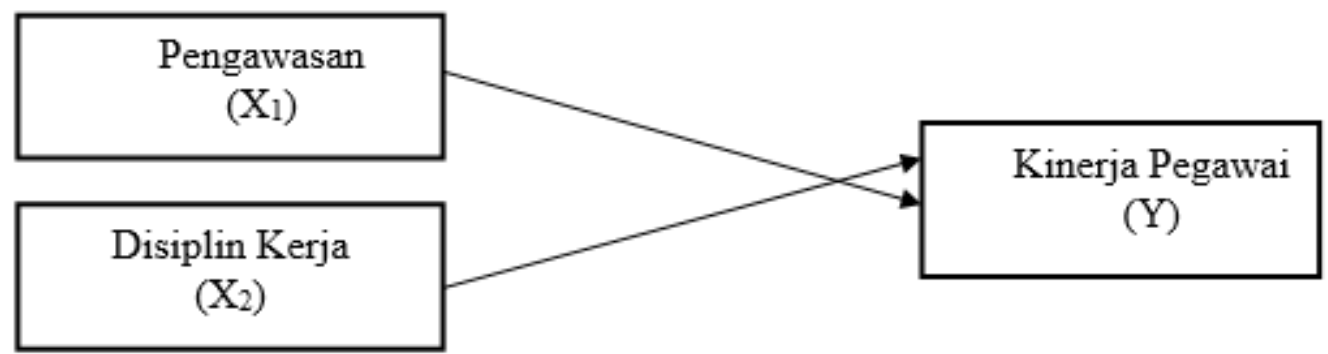

Gambar 1. Kerangka Pemikiran

\section{Hipotesis Penelitian}

Menurut Sugiyono (2014:60) hipotesis penelitian adalah jawaban sementaraa terhadap rumusan masalah penelitian,dimana rumusan penelitian telah dinyatakan dalam bentuk kalimat pertanyaan. Dikatakan sementara karena jawaban yang diberikan baru didasarkan pada teori yang relevan,belum dikatakan fakta-fakta empiris.Berdasarkan uraian diatas, selanjutnya diajukan hipotesis penelitian sebagaiberikut:

H1 : Diduga pengawasan, disiplin kerja secara simultan berpengaruh terhadap kinerja pegawai di Dinas Pendidikan Kota Banda Aceh.

H2: Diduga pengawasan secara parsial berpengaruh terhadap kinerja pegawai di Dinas Pendidikan Kota Banda Aceh.

H3: Diduga disiplin kerja secara parsial berpengaruh terhadap kinerja pegawai di Dinas Pendidikan Kota Banda Aceh

\section{METODE PENELITIAN}

\section{Lokasi dan Objek Penelitian}

Penelitian ini dilakukan pada pegawai Dinas Pendidikan Kota Banda Aceh yang beralamat di Jl. P. Nyak Makam No $23 \mathrm{Kel}$. Kota Baru Banda Aceh. Penelitian ini akan menyajikan tentang bagaimana pengaruh pengawsan, disiplin kerja terhadap kinerja pegawai diDinas Pendidikan Kota Banda Aceh.

\section{Populasi dan Sampel Penelitian}

Menurut Sugiyono (2014:55) populasi adalah wilayah generalisasi yang terdiri dari subyek atau obyek yang mempunyai kualitas dan karakteristik tertentu yang ditetapkan oleh peneliti untuk dipelajari dan kemudian ditarik kesimpulan. Sedangkan sampel adalah sebagaian dari jumlah dan karakteristik yang dimiliki oleh populasi tersebut.Populasi dalam penelitian ini adalah seluruh pegawai pada Kantor Dinas Pendidikan Kota Banda Aceh sebanyak 83 orang. Sampel dalam penelitian ini adalah sebanyak 83 orang pegawai dengan menggunakan model sensus. Menurut Sugiyono (2014:78) sensus adalah teknik penentuan sampel bila semua anggota populasi digunakan sebagai sampel. 


\section{Peralatan Analisis Data}

Peralatan analisis data yang digunakan adalah metode analisis regresi linier berganda yang menjelaskan analisis dan pengaruh antara variabel terikat dengan variabel bebas. Pada model ini menggunakan rumus anlisis regresi linier berganda menurut Sugiyono (2014:211) adalah:

$$
Y=a+b 1 X 1+b 2 X 2+\varepsilon
$$

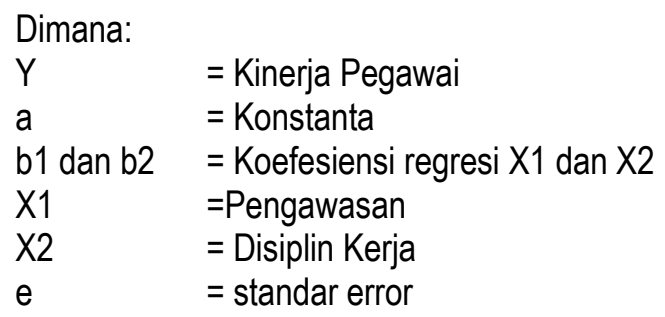

Data yang diperoleh akan diolah menggunakan perhitungan statistik dengan bantuan komputer melalui bantuan program Statistical Product and Service Solution (SPSS). Untuk mencari hubungan antara variabel indenpenden terhadap variabel dependent, digunakan peralatan statistik koefisien korelasi(R). Selanjutnya untuk mengatahui besarnya kedua variabel indenpenden tersebut terhadap variabel dependen yang digunakan koefisien determinasi (R2).

\section{Uji Validitas}

Menurut Arikunto (2011:168) Validitas adalah suatu ukuran yang menunjukkan tingkat-tingkat kevalidan atau kesahihan suatu instrumen. Suatu instrumen yang valid valid atau sahih mempunyai validitas tinggi. Sebaliknya, instrumen yang kurang valid berarti memiliki validitas rendah. Menurut Sugiyono (2014:137) dalam penelitian ini, penentuan validitas dapat dilakukan dengan mencari nilai korelasi skor masing-masing item dengan skor total item untuk setiap variabel. Kemudian nilai rhitung yang diperoleh dari korelasi tersebut dibandingkan dengan nilai rtabel pada tingkat keyakinan 95 persen.

\section{Uji Reliabilitas}

Menurut Sugiyono (2014:121) uji reliabilitas adalah instrumen yang bila digunakan beberapa kali untuk mengukur objek yang sama, akan menghasilkan data yang sama. Setelah instrumen diuji validitasnya maka langkah selanjutnya yaitu menguji reliabilitas. Uji reliabilitas untuk alternatif jawaban lebih dari dua menggunakan uji cronbach's alpha, yang nilainya akan dibandingkan dengan nilai koefisien reliabilitas minimal yang dapat diterima. Jika nilai nilai cronbach's alpha $>0.60$, maka instrumen penelitian reliabel. Jika nilai cronbach's alpha<0.60, maka instrumen penelitian tidak reliabel.

\section{HASIL PENELITIAN DAN PEMBAHASAN}

\section{Gambaran Umum Kantor Dinas Pendidikan Kota Banda Aceh}

Keadaan non pendidikan dimasukkan dalam profil pendidikan karena selama ini terdapat kesan bahwa faktor lingkungan serimg kurang diperhitungkan dalam perencanaan pendididikan sehingga timbul berbagai masalah, antara lain: (1) input pendidikan kurang dikelola secara optimal dan (2) output pendidikan dianggap kurang sesuai dengan kebutuhan masyarakat atau kebutuhan lingkungan, sehingga belum maampu menunjang kebutuhan nasional. Untuk itu, masalah non pendidikan dikaitkan dengan pendidikan yang ada. Administrasi Pemerintahan Daerah sesuai dengan UU No. 22 Tahun 1999, Pemerintah Daerah merupakan koordinator semua instansi sektoral dan kepala daerah yang bertanggung jawab sepenuhnya terhadap pembinaan dan pengembangan wilayahnya.Pembinaan dan pengembangan tersebut mencakup segala bidang kehidupan dan bidang pembangunan dalam rangka meningkatkan kesejahteraan masyarakat. 
Kota Banda Aceh sebagai satu kesatuan wilayah pemerintahan melaksanakan pembangunan yang memiliki arah dan tujuan tertentu yang harus dicapai melalui pembangunan disemua bidang, termasuk dibidang pendidikan dan kebudayaan. Hal itu berarti, bahwa rencana pembangunan pendidikan di Kota Banda Aceh tidaklah berdiri sendiri, tetapi merupakan bagian yang tidak terpisahkan dari rencana pembangunan Kota Banda Aceh secara keseluruhan

\section{Visi dan Misi Kantor Dinas Pendidikan Kota Banda Aceh}

Visi Dinas Pendidikan, Pemuda Dan Olahraga Kota Banda Aceh adalah pendidikan yang bermutu, terampil, daya saing, dan berakhlak mulia di Banda Aceh Model Kota Madani.

Misi Dinas Pendidikan, Pemuda Dan Olahraga Kota Banda Aceh adalah :

1. Kota Banda Aceh menjadi pusat keunggulan pendidikan di Aceh

2. Melaksanakan pendidikan yang merata, dan terbebas dari hambatan biaya

3. Meningkatkan penggelolaan lembaga pendidikan yang prefisional berbasis IT.

4. Meningkatkan peran serta pemuda dalam pembangunan pendidikan

5. Mewijudkan pendidikan yang bermutu untuk menciptakan insan cerdas, terampil dan gemar IPTEK.

6. Berakttualisasi diri melalui olahraga untuk mengwujudkan

7. $\quad$ insan yang sehat, bugar, berdaya tahan, sigap dan terampil

\section{Pengujian Validitas}

Validitas adalah suatu ukuran yang menunjukkan tingkat-tingkat kevalidan atau kesahihan suatu instrumen.Dalam penelitian ini, penentuan validitas dapat dilakukan dengan mencari nilai korelasi skor masingmasing item dengan skor total item untuk setiap variabel. Kemudian nilai rhitung yang diperoleh dari korelasi tersebut dibandingkan dengan nilai rtabel pada tingkat keyakinan 95 persen.Untuk lebih jelasnya mengenai hasil pengujian validitas maka dapat dilihat pada Tabel 1 dibawah:

Tabel 1. Hasil Uji Validitas

\begin{tabular}{|c|c|c|c|c|c|}
\hline No & Variabel & Butir & Nilai $R_{\text {hitung }}$ & Nilai $R_{\text {tabee }}(\mathrm{N}=83)$ & Keterangan \\
\hline \multirow[t]{5}{*}{1} & \multirow{5}{*}{$\begin{array}{c}\text { Kinerja Pegawai } \\
\text { (Y) }\end{array}$} & $\mathrm{A} 1$ & 0,757 & \multirow{5}{*}{0,216} & Valid \\
\hline & & A2 & 0,550 & & Valid \\
\hline & & A3 & 0,464 & & Valid \\
\hline & & A4 & 0,517 & & Valid \\
\hline & & A5 & 0,816 & & Valid \\
\hline \multirow[t]{5}{*}{2} & \multirow{5}{*}{$\begin{array}{c}\text { Pengawasan } \\
\left(X_{1}\right)\end{array}$} & B1 & 0,822 & \multirow{5}{*}{0,216} & Valid \\
\hline & & B2 & 0,640 & & Valid \\
\hline & & B3 & 0,822 & & Valid \\
\hline & & B4 & 0,640 & & Valid \\
\hline & & B5 & 0,661 & & Valid \\
\hline \multirow[t]{5}{*}{3} & \multirow{5}{*}{$\begin{array}{c}\text { DisiplinKerja } \\
\left(\mathrm{X}_{2}\right)\end{array}$} & $\mathrm{C} 1$ & 0,716 & \multirow{5}{*}{0,216} & Valid \\
\hline & & $\mathrm{C} 2$ & 0,535 & & Valid \\
\hline & & C3 & 0,396 & & Valid \\
\hline & & C4 & 0,734 & & Valid \\
\hline & & C5 & 0,624 & & Valid \\
\hline
\end{tabular}

Sumber : Data Primer, 2019 (diolah) yaitu:

Berdasarkan Tabel diatas hasil pengujian vadilitas pada setiap variabel mempunyai nilai yang paling rendah,

1. Hasil pengujian validitasvariabelkinerja pegawaiyang terdiri dari 5 (lima) item pernyataan dilambangkan dengan kode item $A 1, A 2, A 3$ hingga A5menunjukkan rhitung terendah sebesar 0,464lebih besar dari nilai 
rtabel $(n=83)$ sebesar 0,216 . Dengan demikian dapat diartikan seluruh item pernyataan yang berhubungan dengan kinerja pegawaidinyatakan valid.

2. Hasil pengujian validitas variabel pengawasan yang terdiri dari 5 (lima) item pernyataan dilambangkan dengan kode item B1, B2, B3 hingga B5 menunjukkan rhitung terendah sebesar 0,640lebih besar dari nilai rtabel $(n=83)$ sebesar 0,216 . Dengan demikian dapat diartikan seluruh item pernyataan yang berhubungan dengan pengawasandinyatakan valid.

3. Hasil pengujian validitas variabel disiplin kerjaterdiri dari 5 (lima) item pernyataan dengan kode item $\mathrm{C} 1, \mathrm{C} 2$, C3 hingga C5, menunjukkan nilai rhitung terendah sebesar 0,396 lebih besar dari nilai rtabel sebesar $(n=83)$ sebesar 0,216 , sehingga dapat diartikan bahwa seluruh item pernyataan yang berhubungan dengan disiplin kerjadinyatakan valid.

\section{Pengujian Reliabilitas}

Uji reliabilitas adalah instrumen yang bila digunakan beberapa kali untuk mengukur objek yang sama, akan menghasilkan data yang sama. Uji reliabilitas untuk alternatif jawaban lebih dari dua menggunakan uji cronbach's alpha, yang nilainya akan dibandingkan dengan nilai koefisien reliabilitas minimal yang dapat diterima. Jika nilai nilai cronbach's alpha $>0.60$, maka instrumen penelitian reliabel. Jika nilai cronbach's alpha $<0.60$, maka instrumen penelitian tidak reliabel.Untuk lebih jelasnya dapat dilihat pada Tabel 2 dibawah ini.

Tabel 2. Hasil Uji Reliabilitas

\begin{tabular}{|c|l|c|c|c|}
\hline No & \multicolumn{1}{|c|}{ Variabel } & $\begin{array}{c}\text { Jumlah } \\
\text { Item }\end{array}$ & $\begin{array}{c}\text { Nilai } \\
\text { Cronbach Alpha }\end{array}$ & Keterangan \\
\hline 1 & Kinerja Pegawai $(\mathrm{Y})$ & 5 & 0,743 & Reliabel \\
\hline 2 & Pengawasan $\left(\mathrm{X}_{1}\right)$ & 5 & 0,784 & Reliabel \\
\hline 3 & Disiplin Kerja $\left(\mathrm{X}_{2}\right)$ & 5 & 0,719 & Reliabel \\
\hline
\end{tabular}

Sumber: Data Primer (Diolah).

Berdasarkan Tabel diats hasil realibilitas dapat diketahui bahwa Cronbach Aplha masing-masing variabel dapat dilihat dari variabelkinerja pegawai(Y) diperoleh nilaiCronbach alpha sebesar 0,743 , variabelpengawasan(X1) diperoleh nilaiCronbach alpha sebesar 0,784 dan variabel disiplin kerja(X2) diperoleh nilai Cronbach alpha sebesar 0,719. Dengan demikian pengukuran reliabilitas memenuhi kredibilitas CronbachAlpha $>0,60$.

\section{Analisis Pengaruh Pengawasan, Disiplin Kerja Terhadap Kinerja Pegawai Di Dinas Pendidikan Kota Banda Aceh}

Analisis hasil penelitian mengenai pengaruh pengawasan, disiplin kerjaterhadap kinerja pegawai di Dinas PendidikanKota Banda Aceh yang dianalisis dengan model regresi linier berganda. Hal ini ditunjukkan oleh nilai koefisien regresi masing-masing variabel seperti terlihat dalam bagian output SPSS pada Tabel dibawah.

Tabel 3. Nilai Koefisien RegresiMasing-masing Variabel Independen

\begin{tabular}{|c|c|c|c|c|c|c|c|}
\hline \multicolumn{8}{|c|}{ Coefficients ${ }^{a}$} \\
\hline \multirow[b]{2}{*}{ Model } & \multicolumn{2}{|c|}{$\begin{array}{l}\text { Unstandardized } \\
\text { Coefficients }\end{array}$} & \multirow{2}{*}{\begin{tabular}{|c|}
$\begin{array}{c}\text { Standardized } \\
\text { Coefficients }\end{array}$ \\
Beta \\
\end{tabular}} & \multirow[b]{2}{*}{$\mathrm{T}$} & \multirow[b]{2}{*}{ Sig. } & \multicolumn{2}{|c|}{ Collinearity Statistics } \\
\hline & B & Std. Error & & & & Tolerance & VIF \\
\hline $1 \quad$ (Constant) & 5.191 & 1.476 & & 3.518 & .001 & & \\
\hline Pengawasan & .281 & .085 & .329 & 3.300 & .001 & .497 & 2.011 \\
\hline Disiplin Kerja & .487 & .095 & .510 & 5.121 & .000 & .497 & 2.011 \\
\hline
\end{tabular}

a. Dependent Variable: Kinerja Pegawai 
Berdasarkan Tabel diatas maka persamaan regresi yang memperlihatkan kinerjapegawai di Dinas Pendidikan Kota Banda Acehsebagai fungsi dari pengawasan dan disiplin kerja, dapat diformulasikan dalam persamaan berikut:

$$
Y=5,191+0,281 X 1+0,487 X 2+e
$$

Dari persamaan regresi diatas dapat diketahui bahwa hasil penelitian sebagai berikut:

\section{Koefisien Regrisi $(\beta)$}

Adapun koefisien regrisi linier berganda dalam penelitian ini dapat dijelaskan sebagai berikut:

1. Konstanta sebesar 5,191artinya jika pengawasan (X1) dan disiplin kerja (X2) dianggap konstan, maka besarnya kinerja pegawaidi Dinas Pendidikan Kota Banda Aceh adalah sebesar 5,191pada satuan skala likert.

2. Koefisien regresi pengawasan (X1) sebesar 0,281 , artinya bahwa setiap $100 \%$ perubahan dalam variabelpengawasan, maka secara relatif akan mempengaruhi kinerja pegawaidi Dinas Pendidikan Kota Banda Acehsebesar $28,1 \%$, maka semakin tinggi pengaruh pengawasanakan semakin mempengaruhi kinerja pegawaidi Dinas Pendidikan Kota Banda Aceh.

3. Koefisien regresi disiplin kerja (X2) sebesar 0,487 , artinya bahwa setiap 100\% perubahan dalam variabel disiplin kerja, maka secara relatif akan mempengaruhi kinerja pegawaidi Dinas Pendidikan Kota Banda Aceh sebesar 48,7\%, dengan demikian semakin tinggi pengaruhdisiplin kerja maka akan semakin mempengaruhi kinerja pegawaidi Dinas Pendidikan Kota Banda Aceh.

Berdasarkan hasil analisis regresi linier berganda dapat diketahui bahwa dari kedua variabel yang diteliti, ternyata variabel disiplin kerja(X2) mempunyai pengaruh paling dominan terhadap kinerja pegawaidi Dinas Pendidikan Kota Banda Aceh, dengan nilai koefisien sebesar 0,487, kemudian diikuti oleh variabel pengawasan(X1) dengan nilai koefisien sebesar 0,281.

\section{Koefisien Korelasi dan Determinasi}

Untuk melihat hubungan dan pengaruh dari variabel pengawasan, disiplin kerja terhadap kinerja pegawaidi Dinas Pendidikan Kota Banda Acehberdasarkan korelasi dan determinasi dapat dilihat pada Tabel dibawah.

Tabel 4. Nilai Koefisien Korelasi (R)dan Nilai Koefisien Determinasi (R2)

\begin{tabular}{|c|c|c|c|c|c|c|c|c|c|c|}
\hline \multicolumn{11}{|c|}{ Model Summaryb } \\
\hline \multirow[b]{2}{*}{ Model } & \multirow[b]{2}{*}{$\mathrm{R}$} & \multirow[b]{2}{*}{ R Square } & \multirow[b]{2}{*}{$\begin{array}{l}\text { Adjusted R } \\
\text { Square }\end{array}$} & \multirow[b]{2}{*}{$\begin{array}{l}\text { Std. Error of } \\
\text { the Estimate }\end{array}$} & \multicolumn{5}{|c|}{ Change Statistics } & \multirow[b]{2}{*}{$\begin{array}{l}\text { Durbin- } \\
\text { Watson }\end{array}$} \\
\hline & & & & & $\begin{array}{l}\text { R Square } \\
\text { Change }\end{array}$ & $\begin{array}{c}\text { F } \\
\text { Change }\end{array}$ & df1 & df2 & $\begin{array}{l}\text { Sig. F } \\
\text { Change }\end{array}$ & \\
\hline 1 & $.778^{a}$ & .606 & .596 & 1.155 & .606 & 61.409 & 2 & 80 & .000 & 1.941 \\
\hline
\end{tabular}

a. Predictors: (Constant), Disiplin Kerja, Pengawasan

Sumber: Data Primer (Diolah), 2019

Berdasarkan Tabel diatas, maka dapat dijelaskan koefisien korelasi dan determinasi sebagai berikut, yaitu:

1. Koefisien korelasi (R) sebesar 0,778 menunjukkan bahwa hubungan (korelasi) antara variabel bebas dengan variabel terikat sebesar $77,8 \%$, artinya kinerja pegawaidi Dinas Pendidikan Kota Banda Acehmempunyai hubungan yang erat dan positif dengan pengawasan(X1) dan disiplin kerja (X2).

2. Korelasi determinasi (R2) sebesar 0,606 , artinya sebesar $60,6 \%$ perubahan-perubahan dalam variabel terikat yaitu kinerja pegawaidapat dijelaskan oleh perubahan-perubahan dalam pengawasan(X1) dan disiplin kerja (X2). Sedangkan selebihnya yaitu sebesar $39,4 \%$ dijelaskan oleh variabel lain diluar dari pada penelitian ini, misalkankompensasi, motivasi kerja, budaya organisasi, lingkungan kerjadan lain-lain. 


\section{KESIMPULAN DAN SARAN}

\section{Kesimpulan}

Berdasarkan hasil penelitian danpembahasandapat disimpulkan beberapa hal sebagai berikut:

1. Hasil pengujian statistik menunjukkan nilai Fhitung $>$ Ftabel $(81,932>3,112)$ Artinyapengawasan(X1) dan disiplinkerja(X2)secara simultan berpengaruh signifikan terhadap kinerjapegawaidiDinasPendidikan Kota Banda Aceh, sehingga hipotesis Ha diterima.

2. Hasil pengujian statistik untukvariabel pengawasan(X1) menunjukkan nilai thitung>ttabel $(3,300>1,989)$. Artinyapengawasansecaraparsial berpengaruh signifikan terhadap kinerjapegawaidiDinasPendidikan Kota Banda Aceh, sehingga hipotesis pertama Ha diterima.

3. Hasil pengujian statistik untukvariabel disiplinkerja(X2) menunjukkan nilai thitung>ttabel $(5,121>1,989)$. Artinyadisiplinkerjasecara parsial berpengaruh signifikan terhadap kinerjapegawaidiDinasPendidikan Kota Banda Aceh, sehingga hipotesis kedua Ha diterima.

4. Nilaikoefisien korelasi $(R)$ sebesar 0,778 menunjukkan bahwa hubungan (korelasi) antara variabel bebas dengan variabel terikat sebesar $77,8 \%$, artinya kinerjapegawaidiDinasPendidikan Kota Banda Aceh mempunyai hubungan yang erat dan positif dengan pengawasan(X1) dan disiplinkerja(X2).

5. Nilai korelasi determinasi (R2) sebesar 0,606 , artinya sebesar $60,6 \%$ perubahan-perubahan dalam variabel terikat yaitu kinerjapegawaidapat dijelaskan oleh perubahan-perubahan dalam pengawasan(X1) dan disiplinkerja(X2). Sedangkan selebihnya yaitu sebesar 39,4\% dijelaskan oleh variabel lain diluar dari pada penelitian ini, misalkankompensasi, motivasikerja, budaya organisasi, lingkungankerjadan lain-lain

\section{Saran}

Berdasarkan kesimpulan yang diperoleh dari hasil penelitian, beberapa saran yang diusulkan adalah:

1. Pada Kantor Dinas PendidikanKota Banda Aceh

a. Dengan diketahui pengaruh pengawasandan disiplinkerjaberpengaruh terhadap kinerja pegawai diharapkan semakin mendorong manajemen pada Kantor Dinas Pendidikan Kota Banda Aceh tidak raguragu menerapkan pengawasandan disiplin kerjadalam meningkatkan kinerja pegawai.

b. Variabel pengawasan merupakan variabel yang paling sedikit pengaruhnya terhadap kinerja pegawai pada Kantor Dinas PendidikanKota Banda Aceh dibandingkan dengandisiplinkerja. Untuk itu pihak pada Kantor Dinas PendidikanKota Banda Acehhendaknya lebih menekankan pada pengawasan untuk para pegawai agar kinerja pegawai dapat meningkat dalam mencapai tujuan instansi.

\section{REFERENSI}

[1] Aprianita, Riza. 2013. Pengaruh Pengawasan, Komitmen Dan Disiplin Kerja Terhadap Kinerja Pegawai Pada Dinas Pendidikan Kabupaten Pasaman. Jurnal.UniversitasNegeri Padang: Padang.

[2] Arikunto, S. 2011. Prosedur penelitian: Suatu Pendekatan Praktik. (Edisi. Revisi). Rineka Cipta: Jakarta.

[3] Bonar P. Silalahi, KhairaAmalia F, danMuslichLufti. 2014. Pengaruh Motivasi, Pengawasan Dan Disiplin Kerja Terhadap Prestasi Kerja Pegawai Dinas Pendapatan, Pengelola Keuangan Dan Kekayaan Daerah KabupatenTapanuli Tengah. Jurnal.Universitas Terbuka: Tapanuli.

[4] Dharma, Surya. 2009. Manajemen Kinerja Falsafah Teori dan Penerapannya. Penerbit Pustaka Pelajar: Yogyakarta.

[5] Fathoni, Abdurrahmat. 2009. Manajemen Sumber daya Manusia. Rineka Cipta: Jakarta.

[6] Handoko, T. Hani. 2009.Manajemen Personalia dan Sumber Daya Manusia. BPFE: Yokyakarta.

[7] Harahap, SofyanSyafri. 2011. SistemPengawasanManajemen. Pustaka Quantum: Jakarta.

[8] Hasibuan, Malayu S.P. 2013. Manajemen Sumber Daya Manusia, Edisi Revisi. Bumi Aksara: Jakarta. 
[9] Mahmudi. 2010. Manajemen Kinerja SektorPublik. Upp STIM YKPN: Yokyakarta.

[10] Mahsun, Mohamad, 2009. Pengukuran Kinerja Sektor Publik. Penerbit BPFE: Yogyakarta.

[11] Maisyura.2014. Pengaruh Gaya Kepemimpinan Dan Disiplin Kerja Terhadap Kinerja Pegawai Pada Kantor Walikota Banda Aceh.Skripsi. Universitas Serambi Mekkah: Banda Aceh.

[12] Malthis, Robert. L dan Jackson, John H. 2009. Manajemen Sumber Daya Manusia. Salemba Empat: Jakarta.

[13] Mangkunegara, Anwar Prabu. 2013.Manajemen Sumber Daya ManusiaPerusahaan. PT. Remaja Rosda Karya: Bandung.

[14] Maringan. 2010.Dasar-dasar dan Administrasi Manajemen. Penerbit Pustaka Quantum: Jakarta.

[15] Moeheriono.2010. Pengukuran Kinerja Berbasis Kompetensi. PenerbitGhalia Indonesia: Bogor.

[16] Mulyadi.2009. Sistem Perencanaan dan Pengendalian Manajemen Sumber Daya Manusia.EdisiKesatu. CetakanKedua. SalembaEmpat: Jakarta.

[17] Nawawi, Hadari.2008.Manajemen Sumber Daya Manusia Untuk Bisnis Yang Kompetitif. Gajah Mada University Press: Yogyakarta.

[18] Nitisemito, S Alex.2010. Dasar-dasar Manajemen. Penerbit Ghalia Indonesia: Jakarta.

[19] Rahayu, EtiDwi. 2008. Pengaruh Disiplin Kerja Dan Pengawasan Kerja Terhadap Efektivitas Kerja Pegawai Pada Badan Kepegawaian Daerah Kota Semarang.Skripsi.UniversitasNegeri Semarang: Semarang.

[20] Rivai, Veithzal. 2009. Manajemen Sumber Daya Manusia. Rajagrafindo Persada: Jakarta.

[21] Rivai, Veithzal dan Basri. 2009. Performance Appraisal: Sistem Yang Tepat Untuk Menilai Kinerja Karyawan Dan Meningkatkan Daya Saing Perusahaan. Penerbit Rajagrafindo Persada: Jakarta.

[22] Rivai, Veithzal dan Sagala, Ella J. 2010. Manajemen Sumber Daya Manusia Untuk Perusahaan. Raja Grafindo Persada: Jakarta.

[23] Sarboini. 2016. Performance of Employees and Impect On Promotion of Posision. Jurnal IImiah Peuradeun Vol. 4, No. 1, January 2016 hal ( 103-113).

[24] Saydam, Gouzali. 2009. Manajemen Sumber Daya Manusia. Penerbit PT. Toko Gunung Agung: Jakarta.

[25] Sedarmayanti. 2011. Manajemen Sumber Daya Manusia. Edisi Kelima. Rafika Aditama: Bandung.

[26] Setiyawan,PurnomoBudhidanWaridin.2009. Pengaruh DisiplinKerja Karyawan dan Budaya Organisasi terhadap Kinerja Di Divisi Radiologi RSUP DokterKariadi Semarang.Jurnal.Universitas Islam Sultan Agung: Semarang.

[27] Siagian, Sondang. 2009. Manajemen Sumber Daya Manusia. Bumi Aksara: Jakarta..

[28] Sugiyono. 2014. Metode Penelitian Kuantitatif Kualitatif Dan R\&D.Penerbit Alfabeta: Bandung.

[29] Sutrisno, Edi. 2013. Manajemen Sumber Daya Manusia. Kencana Prenada Media Group: Jakarta.

[30] Winardi. 2011. Motivasi Pemotivasiaan. Penerbit PT. RajaGrafindo Persada: Jakarta. 